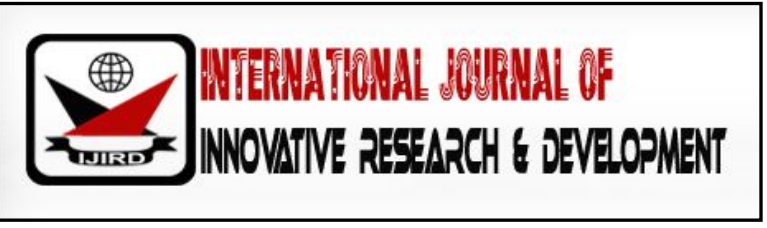

ISSN 2278 - 0211 (Online)

\title{
Correlates Of Senior High School Students' Attitude And Internet Usage
}

\begin{tabular}{c}
\hline Helena Naa Kokor Tetteh \\
Tutor, Department of Mathematics and ICT, Berekum College of Education, Ghana \\
Douglas Darko Agyei \\
Professor, Department of Mathematics and ICT Education, University of Cape Coast, Ghana \\
Daniel Ashong \\
Tutor, Department of Mathematics and ICT, Berekum College of Education, Ghana
\end{tabular}

\begin{abstract}
:
This study examined the relationship between Senior High School students' attitudes towards internet and their actual usage in the Cape Coast Metropolis of Ghana. A correlational research design was used to examine 200 students' internet usage and their attitudes: perceived usefulness, perceived ease of use and subjective norms guided by the Technology Acceptance Model. Data was analyzed using correlation, linear regression and independent samples t-test. Although, the results showed a positive linear relationship between all the attitudinal dimensions of internet usage: the strongest predictor of internet usage reported by the students was their perceived ease of use of the internet. It was also evident from the findings that female students reported higher internet usage than their male counterparts. One of the implications of these findings is that instructional designers and researchers should design instructions that integrate ICT and internet into the teaching and learning processes as the internet is source endowed with rich materials for teachers' teaching and students' conceptual development.
\end{abstract}

Keywords: Internet, attitude, technology acceptance model

\section{Introduction}

\subsection{Background}

The internet is the global system of interconnected computer networks that use the Transmission Control Protocol/ Internet Protocol suite (TCP/ IP) to link billions of devices worldwide. It is a network of networks that consists of millions of private, public, academic, business, and government networks of local to global scope, linked by a broad array of electronic, wireless, and optical networking technologies. The internet carries an extensive range of information resources and services, such as the inter-linked hypertext documents and applications of the World Wide Web (WWW), electronic mail, telephony and peer-to-peer networks for file sharing (Stewart, 2000).

Today, the internet is increasingly making its presence felt, not only playing an important role in research and education but also serving as a catalyst to a country's socio-economic, cultural and political development. It is therefore not surprising that the internet has become a developmental tool of the highest significance. Internet use grew rapidly in the West from the mid-1990s and from the late 1990s in the developing world. In the 20 years since 1995, internet use has grown 100times, measured for the period of one year, to over one third of the world population (Stewart, 2000).

The use of computer technology for teaching and learning began to receive government of Ghana's attention from the late 1990s. The information and communications technology in education policy of Ghana requires the use of information and communications technology for teaching and learning at all levels of education. The Ministry of Education (MOE) supports institutions in teaching of information and communications technology literacy. Majority of secondary schools and some basic schools of Ghana have computer laboratories. There are quite a number of initiatives that are brewing to further develop internet connectivity in Ghana, some of it with funding for the universities, public services etc. (Arthur \& Brafi, 2013).

In a recent study, (Ahmad; Hunjra; Safwan \& Rehman, 2010) expressed concern about the emergence of a digital divide between majority and minority groups. The researchers surveyed 226 students of first year Hispanic college students enrolled in an intensive course of doctrinal in the southwest, to ask questions about their attitude towards the use of internet and technology applications. Almost all students at various levels have certain experiences of using the internet. With the wide 
application of teaching internet-based learning, these students may have more and richer learning environments based on internet. However, studies on the fundamental nature of student use of internet have not kept pace with their internet use (Metzger, Flanagin, \& Zwarun, 2003).

In addition, to make proper use of internet in schools, colleges and universities, there is the need to understand the attitudes of students toward the use of it (Ahmad; Hunjra; Safwan \& Rehman, 2010). According to Agyei (2015), the integration of ICT into Ghana's educational system was formally introduced as part of educational reforms which began in September 2007 as part of government's initiative to improve quality teaching and learning in the nation's schools. One major requirement of the 2007 educational reform was to ensure that all students in pre-tertiary institutions in Ghana acquire basic ICT literacy (including internet use) and apply these to their studies and in their everyday life activities (CRDD, 2007a). This study therefore sorts to examine the relationships between students' attitude and the use of internet in the Cape Coast Metropolis in the Central Region of Ghana.

\subsection{Review of Related Literature}

\subsubsection{Attitude towards Internet and Gender Differences}

According to Tuncer (2013), the attitude towards internet is defined as the feelings, thoughts and experiences regarding internet activities. Binder \& Niederle, (2007), referred to attitude as one's positive or negative judgment about a concrete subject. Attitudes are learnt; they are moldable and may change with experience of the stimulus objects and with social rules or institutions (Nabeel, Shahrir \& Hai, 2013). Mitra \& Steffensmeier (2000) stated that a networked learning institution where students have easy access to computers could foster positive attitudes toward the use of computers in teaching and learning (Hong, Ridzuan, \& Kuek, 2003).

Recent research indicates that attitude represents a summary evaluation of a psychological object and is described both internally and externally in dimensions such as good-bad, likeable-dislikeable, harmful-beneficial, pleasant-unpleasant (Ajzen \& Fishbein, 2000). Attitudes toward information and communication technology (ICT) usage have been defined as a person's general evaluation or feeling towards ICT and specific computer and internet related activities (Smith, Caputi, \& Rawstone, 2000). The learner attitude towards computer measures a person's capabilities in effective learning. Garland \& Noyes (2005) indicated that in the educational context, confidence should lead to more positive attitudes toward computers and internet, and this will enhance learning and associated activities. Attitude, in turn, constitutes various dimensions. Some examples of these are perceived usefulness, computer confidence, anxiety, and liking.

Some studies show that male students experience more positive emotions and perceptions towards the internet as compared to female students (Durndell, Haag, \& Laithwaite, 2000; Sam, Othman, \& Nordin, 2005), but the reverse situation may also be encountered (Brosnan \& Lee, 1998; Morris \& Trushell, 2014). Male students report more favourable attitudes towards the internet, are more confident with using it as compared to the female students. Other studies do not encounter gender differences between groups as far as the internet attitude or self-efficacy scores are concerned (Joyce \& Kirakowski, 2013).

\subsection{Theory of Acceptance Model (TAM)}

The most well-known and widely accepted and cited model is the technology acceptance model [TAM] (Davis, Bagozzi \& Warshaw, 1989), TAM was adapted from the Theory of Reasoned Action (-TRA-). Davis (1989) developed the TAM to explain the computer usage and acceptance of information technology. According to Davis $(1993, \mathrm{p} .1)$ 'user acceptance is often the pivotal factor that determines the success or failure of an information system'. The term external variables include all the system design features. These features have a direct influence on perceived usefulness (PU) and perceived easy of use (PEOU), while attitude towards using has an indirect influence effect to the actual system use.

Davis (1993, p. 477) defined PEOU as "the degree to which an individual believes that using a particular system would be free of physical and mental effort", and PU as "the degree to which an individual believes that using a particular system would enhance his/ her job performance. As Davis, Bagozzi \& Warshaw (1989) stated, the goal is to provide us with an explanation of the determinants of information systems acceptance. Similar to TRA user beliefs determine the attitude toward using the information system. This attitude drives to intention behavior to use which lead to actual system use. Though Dishaw \& Strong (1999, pp. 9-21) pointed out a weak point of TAM about task focus, and that to them TAM differs from TRA "in two keys". The first key is that define PEOU and PU as external variables that determine the intention to use not the actual use. The second key is that TAM does not include subjective norms. Due to the weak point of TAM as pointed out by Dishaw $\&$ Strong (1999, pp. 9-21), Venkatesh \& Davis (2000), proposed an extension of TAM, the TAM2. TAM2 includes social influence process such as subjective norm, and cognitive instrumental process such as job relevance, output quality and result demonstrability.

Although the TAM model has evolved, the attitude toward behavior, subjective norm and behavioral intention components are common to both TAM and TRA models, acknowledging that attitude and subjective norms have an influence on the intention to use ICT leading to their actual use of ICT. The Theory of Planned Behavior (TPB) was developed from the TRA, and it led researchers to consider the use of the TPB for predicting people's behavior towards technology use. Mathieson (1991) suggested that, while TAM is useful for gathering general information about people's perception of a system, TPB can 
provide detailed information regarding each of its components that might relate to a specific group of people. The TRA and the TPB have continued to be employed and adapted by researchers to predict behavior towards ICT usage.

\subsection{Perceived Usefulness (PU)}

PU is defined as "the degree to which a person believes that using a particular system would enhance his or her job performance" (Davis, 1989). Mathwick, Malhotra, \& Rigdon, (2001) also defined perceived usefulness as the extent to which a person deems a particular system to boost his or her job performance. Within the organizational context, a system that is high in perceived usefulness is one that the user believes will have a positive user performance relationship. In fact, IS adoption research suggests that "a system that does not help people perform their jobs is not likely to be received favourably" (Nysveen, Pedersen, \& Thornbjomsen, 2005, p. 537). The ultimate reason that students' exploit the internet is that they find the systems useful to their information needs or search tasks (Hong, Thong, Wong, \& Tam 2002).

\subsection{Perceived Ease of Use (PEOU)}

Researchers argue that perceived ease of use is the extent to which a person accepts as true that using an exacting method would be at no cost to that individual (Davis, Bagozzi \& Warshaw, 1989; Gefen \& Straub, 2000; Gahtani, 2001; Mathieson, 1991). The easier it is for a user to interact with a system, the more likely he or she will find it useful (Thong, Hong, $\&$ Tam, 2004).).

\subsection{Subjective Norms ( SN)}

Ajzen (1991); Taylor \& Todd (1995); Venkatesh \& Davis (2000) founded a significant direct effect of subjective norm on intention. According to Venkatesh \& Davis (2000) the rational for a direct effect of subjective norm on intention is that people may choose to perform a behavior, even if they are not themselves favorable toward the behavior or its consequences, if they believe one or more important referents think they should, and they are sufficiently motivated to comply with the referents. Taylor \& Todd, (1995) suggested that in a setting where actual behavior with real consequences is studied, subjective norm would be expected to be an important determinant of intention and usage.

\subsection{Internet Usage (IU) and Gender Differences}

According to Bavukutty \& Salih (1999) students', research schools, and teachers use the internet for the purpose of study, research and teaching respectively. The purposes of internet use were: sending and receiving e-mails in connection with academic requirements, making a search on library catalogues, downloading images and communication with the peer. Sanni, Awoleye, Egbetokun, \& Siyanbola, (2009), observed that there is a gender difference in internet use and thus adequate attention should be paid to ensuring equal access between male and female students. There are however numerous debates on the link between gender and Internet usage. Many researchers are aware of gender inequality in internet usage. Gender inequalities are not only reflected in internet technology but also in numerous aspects such as in education, politics, and workforce. Akman \& Mishra (2009), found the difference in internet usage among male and female (difference). Hills \& Argyle (2003) found that males use more internet than females and the report also show the evidence of male dominance and female resistance on the internet usage. There are gender differences and inequality in both internet access and intensity of use. Bimber (2000) found that the gender gap in the internet is larger where more intensive Web use is concerned. Women are substantially less likely to be frequent users, equally likely to be infrequent users, and more likely to be intermediate users. In short, females are less intensive internet users than males (Bimber, 2000).

\section{Conceptual Framew ork of the Study}

Pertaining to this study, Perceived Usefulness refers to individual's beliefs about the usefulness of internet, availability, relevance and worth of using internet in their life now and in the future and whether they enjoy working on the internet whereas, Perceived Ease of Use refers to how the use of the internet will describe students' performance that is, its usability and accessibility in their field of study. On the other hand, Subjective Norms will encompass the consequences of using the internet, that is, does the individual feels secured, being motivated and has s/ he got any privacy in using the internet.

Based on the extension of TAM that is TAM 2, the present study examines the impact of the perceived usefulness, the perceived ease of use and the subjective norms of internet usage (see Figure 1). The model includes variables such as internet usage, the perceived variables and subjective norms. 


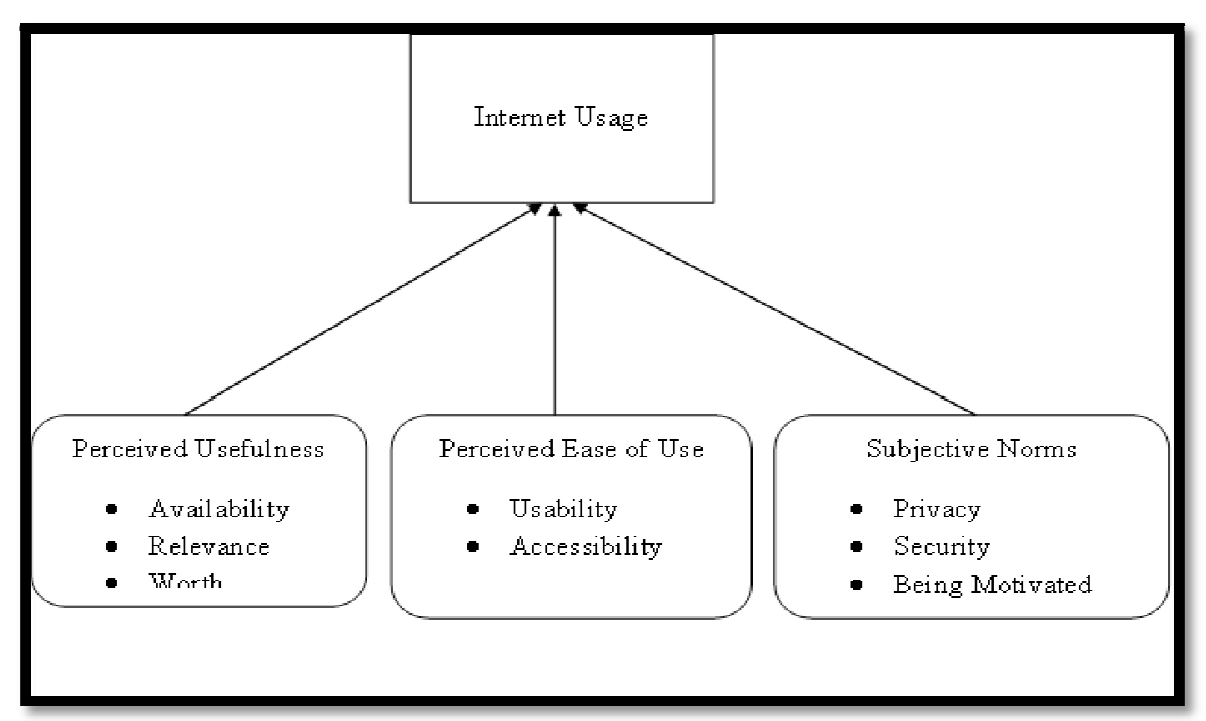

Figure 1: A Visual Model of the Conceptual Framework

\subsection{Purpose of the Study}

The study aimed at examining the relationships between internet usage among Senior High School students in Cape Coast Metropolis. The further helped -to established whether there was any difference between male students and their female counterparts on their attitudes toward the usage of the internet in learning mathematics.

The following research questions were formulated to help achieve the purpose of the study-:

- Is there any relationship between internet usage and students' perceived usefulness; students' perceived ease of use and students' subjective norms of the internet respectively?

- To what extent do students' perceived usefulness of the internet; students' perceived ease of use of the internet and students' subjective norms of the internet respectively predicts internet usage?

- Is there any gender difference in students' attitude towards internet usage?

\section{Methodology of the Study}

\subsection{Research Design}

The study used correlational research design to examine whether there was any relationship between students' use of internet and their attitude towards internet. The correlation design was used because the study was not intended to manipulate students' internet usage and their attitudes towards it. Though the variables; perceived usefulness, ease of use, and subjective norms of internet usage do exist in the literature but the purpose of the study was to examine the existence of any relationship among them. A cross-sectional survey therefore was used to collect data from high school students to address the current purpose of the study.

\subsection{Sample and Sampling Procedure}

The cross-sectional survey was conducted in Cape Coast Metropolis. Students from Senior High Schools (SHS) were involved in the survey. There were 12 senior high schools in the metropolis and they were stratified into male single sex, female single sex, and co-educational schools. Of the 12, 25\% were male single sex schools, $16.7 \%$ were female single sex schools, and 58.3\% were co-educational schools. One school from each stratum was simple randomly selected to participate in the survey.

There were three-year groups (SHS 1, SHS 2, and SHS 3) of students present in each school. The SHS3 students were writing their final examination hence were not included in the study. It was envisaged that the SHS1 students had not have enough access to high school ICT and internet usage to effectively perform well on the items. Consequently, a decision was made to use the SHS 2 students. The SHS 2 groups were simple randomly selected to participate in the survey. There was a total of 200 SHS 2 students from the three schools comprising 50, 50, and 100 students respectively from the male single sex, female single sex, and co-educational schools. In all there were 200 students comprising 100 males and 100 females who participated in the study.

\subsection{Research Instruments}

The instrument used for this study was a questionnaire which was used to assess the relationships of internet usage among students in Cape Coast Metropolis. It was developed based on instruments developed by Slate, (2002), utilized by Usun (2003) slightly modified by Ahmad; Hunjra; Safwan \& Rehman, (2010) into a scale of 17 items and was then merged with a 
scale of 27 items by Khaled, (2012) as well as reviewed by Doggan, Hess, Mogan, Kim, \& Wilson, (1999); Hong, Thong, Wong, \& Tam, (2002). These two scales were slightly modified to form a scale of 25 items which were used specifically for this study.

The scale of 25 items specifically for the study was constructed using perceived usefulness, ease of use, and subjective norms of internet usage. Thus, in all, a number of statements designed to measure each of these three issues on attitude towards internet usage were given to the students to respond to. A four-point Likert scale was used for internet usage ('Always =4, Most at Times =3, Hardly =2, Not at All =1) and a four-point Likert scale was used for perceived usefulness, ease of use and subjective norms (where $4=$ strongly agree, 3 =agree, 2 =disagree, 1 =strongly disagree). The internal consistency reliabilities for students' attitude towards the internet usage sub-scales as reported by the students. The items could be classified under 4 sub-scales: Internet usage (Cronbach's $\alpha=0.945$ ), perceived usefulness (Cronbach's $\alpha=0.971$ ); perceived ease of use (Cronbach's $\alpha=0.955$ ) and subjective norms (Cronbach's $\alpha=0.954$ ).

\subsection{Data Collection Procedure}

A survey-questionnaire approach was used to gather data in the study. A questionnaire was personally administered to the students in each school, after the normal school hours so as not to disrupt classes. This method is chosen because the designed questionnaire could be collected within a short period of time and any doubt that the respondents might have on any question could be clarified on the spot (Sekaran, 2003). Students in each participating school were given 30 minutes to complete the instrument under the supervision of the Assistant Head Master (Academic) and the author too. Responses were then collated.

\subsection{Data Analysis Procedure}

To analyze the quantitative data descriptive statistics, a bivariate correlation analysis, a linear regression analysis and independent samples t-test were conducted in SPSS. Effect size was calculated using Cohen's d (Cohen, 1988).

\section{Results}

\subsection{Internet Usage and Students' Perceived Usefulness, Perceived Ease of Use and Subjective Norms of the Internet}

The first research question dealt with in the study was whether there exists any relationship between internet usage and students' perceived usefulness; students' perceived ease of use and students' subjective norms of the internet respectively. To achieve this, a Pearson product-moment correlation was calculated between the various attitudinal variables and internet usage. Correlations were significant for "perceived usefulness" ( $r=0.956, p<0.001)$; "perceived ease of use" ( $r=$ $0.971, \mathrm{p}<0.001)$ and "subjective norms" ( $\mathrm{r}=0.949, \mathrm{p}<0.001)$ at 0.01 levels of significance respectively. However, a strong positive relationship was found between Perceived ease of use and internet usage. This seems to suggest that students have access as well as use the internet in their learning (see Table 1).

\begin{tabular}{|c|c|c|c|c|}
\hline & $\begin{array}{c}\text { Perceived } \\
\text { Usefulness }\end{array}$ & $\begin{array}{c}\text { Perceived Ease } \\
\text { of Use }\end{array}$ & $\begin{array}{c}\text { Subjective } \\
\text { Norms }\end{array}$ \\
\hline Internet Usage & Pearson Correlation & $0.956^{* *}$ & $0.971^{* *}$ & $0.949^{* *}$ \\
\hline & Sig. (2-tailed) & 0.000 & 0.000 & 0.000 \\
\hline & $\mathrm{N}$ & 200 & 200 & 200 \\
\hline
\end{tabular}

Table 1: Correlation between the Dependent Variable and the Independent Variables

**. Correlation Is Significant at the 0.01 Level (2-Tailed)

The relationship was further explored graphically. Figure 2 illustrates the relationship between internet usage and students' perceived usefulness, perceived ease of use and subjective norms of the internet. There seems to be a strong positive relationship between perceived ease of use and internet usage. This is therefore an indication that perceived ease of use is a good predictor of internet usage. 


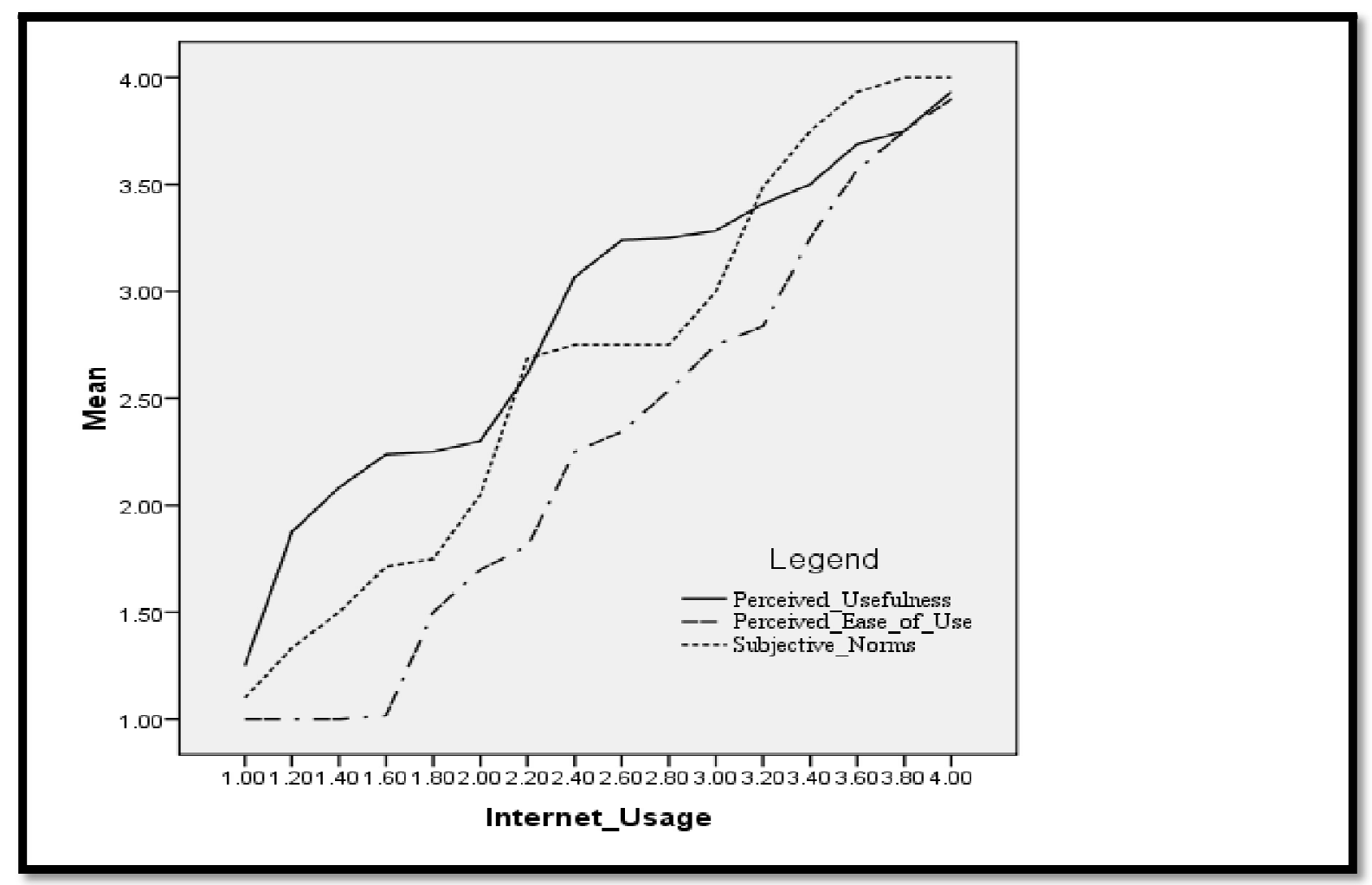

Figure 2: Students' Attitudes toward Internet Usage

\subsection{Impact of Perceived Usefulness, Perceived Ease of Use and Subjective Norms of the Internet on Internet Usage}

Research Question 2 sought to examine the extent of students' perceived usefulness, ease of use, subjective norms in prediction of internet usage. A regression analysis model was used. The regression equation with all the three predictors was significantly related to internet usage $\left(R^{2}=0.968, \mathrm{~F}-(3,196)=1997.793, \mathrm{p}<0.000\right)$. The standardized coefficients of the various predictors were $0.504,0.278$ and 0.225 for perceived ease of use (PEOU), perceived usefulness (PU), and subjective norms (SN) of the internet respectively.

According to the standardized coefficients the regression model is Internet Usage $=0.504 \mathrm{PEOU}+0.278 \mathrm{PU}+0.225 \mathrm{SN}$ As shown in the model, perceived ease of use appeared to be a strong predictor of internet usage while perceived usefulness and subjective norms appeared to be quite acceptable. It is therefore clear that there is a positive relationship between the dependent variable (Internet Usage) and the independent variables, (perceived usefulness; perceived ease of use and subjective norms) with a significant value of 0.000 . The regression analysis verified that the F-value was significant indicating that the independent variables predict the dependent variable (see Table 2).

\begin{tabular}{|c|c|c|c|c|c|c|}
\hline & R & R-square & F (Sig.) & $\begin{array}{c}\text { Standardized } \\
\text { Coefficients }\end{array}$ & sig \\
\hline Impact of PEOU, & 0.984 & 0.968 & $1997.793(0.000)$ & 0.504 & 12.649 & 0.000 \\
PUand SN on & & & & 0.278 & 7.027 & 0.000 \\
internet usage & & & & 0.225 & 5.973 & 0.000 \\
\hline
\end{tabular}

Table 2: Coefficients of Predictors (Perceived Ease of Use, Perceived Usefulness and Subjective Norms of Internet Usage)

PEOU $=$ Perceived Ease of Use

$\mathrm{PU}=$ Perceived Usefulness

$\mathrm{SN}=$ Subjective Norms

\subsection{Gender Differences in Attitude towards Internet Usage}

Research Question 3 sought to find out if there was any gender difference in students' attitude towards internet usage. Table 3 shows the results on male and female students' attitude towards internet usage. The difference in means of internet usage for the male students $(\mathrm{M}=2.3480, \mathrm{SD}=0.69662)$ and female students $(\mathrm{M}=2.6800, \mathrm{SD}=0.6869)$; $\mathrm{t}(198)=-3.393$ was significant with $(p=0.001)$ and a small effect size $(d=0.48)$. Thus, the female students seem to report a higher internet usage than the male counterparts. 


\begin{tabular}{|c|c|c|c|c|c|c|c|c|}
\hline & Sex & $\mathbf{N}$ & Mean & $\begin{array}{c}\text { Std. } \\
\text { Deviation }\end{array}$ & Sig. & T & $\begin{array}{c}\text { Sig. } \\
\text { (2-Tailed) }\end{array}$ & Effect Size \\
\hline $\begin{array}{c}\text { Internet } \\
\text { Usage }\end{array}$ & Males & 100 & 2.3480 & 0.69667 & 0.343 & -3.393 & 0.001 & 0.48 \\
\hline & Females & 100 & 2.6800 & 0.68696 & & & & \\
\hline \multicolumn{7}{|c|}{ Table 3: Results of Group Statistics and Independence Samples Test }
\end{tabular}

\section{Discussion}

The study was designed to explore the correlates of senior high school students' attitude toward internet usage in the cape coast metropolitan of Ghana in internet usage. The results from the regression analyses shows that there is a positive relationship between internet usage and perceived usefulness of the internet; internet usage and perceived ease of use of the internet and internet usage and subjective norms of the internet among students respectively. From the regression analyses, the results however showed that out of the three independent variables, perceived ease of use predicted internet usage more. The study is therefore in line with (Davis, Bagozzi \& Warshaw, 1989; Gefen \& Straub, 2000; Gahtani, 2001; Mathieson, 1991) that perceived ease of use is the extent to which a person accepts as true that using an exacting method would be at no cost to that individual. The easier it is for a user to interact with a system, the more likely he or she will find it useful (Thong, 2004). The results of the Independence samples t-test on the other hand, was used to find out if there is gender difference in attitude towards internet usage, the result therefore shows that there was statistically significant difference in internet usage among male and female students and this was in the direction of the female students. The effect size calculated revealed that only $48 \%$ of the variance in internet usage was explained by sex of the respondents. Both male and female students demonstrated a positive attitude towards internet usage. But the findings in this study is contrary to findings in other studies that male students tend to have more positive attitudes towards internet usage than female students (Bimber, 2000; Hills \& Argyle, 2003; Akman \& Mishra, 2009).

\section{Implications and Recommendations}

The study showed a significant amount of variation in students' attitude towards internet usage. This might be because Cape Coast schools are known to be more endowed in infrastructure and all other facilities hence the reason for a strong relationship of internet usage and the independent variables among students. It could also be that students from these schools are from wealthy homes and might have access to internet as well as more exposed to its usage. Parent Teachers' Association, School Management and Boards might have provided ICT facilities in these schools to facilitate and increase access to internet usage among students. Hence the easy access to internet usage will certainly have contributed their positive relationship of internet usage in these schools. It is recommended that the Ghana Education Service (GES) should strengthen and enforce policies regarding the practical use of ICT for educational practices in the curriculum. A clear articulation of policy within the framework of the teacher education institution and GES could ensure better grounding of internet usage in education in Ghana. Instructional designers and researchers should design instructions that integrate ICT and internet into the teaching and learning processes as the internet is source endowed with rich materials for teachers' teaching and students' conceptual development.

\section{Limitations}

This study was not without some limitations. One limitation of the study was that with regards to the internet usage, students were given sample questions to answer instead of being observed while they use the internet. Another limitation of the study was that, the data was collected from three Senior High Schools in Cape Coast Metropolis, hence the findings were limited to second year students in these schools. The study which was conducted with 200 students from only three Senior High Schools in Cape Coast which were sufficiently endowed with internet facilities provides no evidence on whether the findings of this study reflect the situation in the whole of Cape Coast Metropolis. Finally, the respondents were randomly selected and it is to this group that generalizations were made.

\section{Conclusion}

In terms of answering the questions that guided this study, it was concluded, following the results of the analyses that there seems to be a strong positive relationship between perceived ease of use and internet usage. The study showed that perceived ease of use was the strongest predictor of internet usage by students. The study is therefore in line with (Davis, Bagozzi \& Warshaw, 1989; Gefen \& Straub, 2000; Gahtani, 2001; Mathieson, 1991) that perceived ease of use is the extent to which a person accepts as true that using an exacting method would be at no cost to that individual. The easier it is for a user to interact with a system, the more likely he or she will find it useful (Thong, 2004). Female students reported high internet usage than their male counterparts. The findings of this study are contrary to (Bimber, 2000; Hills \& Argyle 2003)'s study that male students tend to have more positive attitudes towards internet usage than their female counterparts. Notwithstanding the limitations, it is necessary to take some measures in order to help implement internet usage in secondary schools in Ghana. 


\section{References}

i. Agyei, D. D. (2015). Evaluating teachers' professional development for ICT use: towards innovative classroom practices. International Journal of Education, Learning and Development, 3(9), 28-45.

ii. Ahmad, A., Hunjra, A. I., Safwan, N. \& Rehman, K. Ur, (2010). Students' Attitude towards the use of the internet: A study at the universities of the twin cities (Islamabad and Rawalpindi). International Journal of Business and Management.

iii. Arthur, C. \& Brafi, P. O. (2013). "Internet Use among Students in Tertiary Institutions in the Sunyani municipality, Ghana": Library Philosophy and Practice (e-journal), p. 858.

iv. Ajzen, I. (1991). The theory of planned behavior. Organizational Behavior and Human Decision Processes, 50, 179211.

v. Ajzen, I., \& Fishbein, M. (2000). Attitudes and the attitude-behavior relation: Reasoned and automatic processes. In W. Stroebe \& M. Hewstone (Eds.), European Review of Social Psychology (pp. 1-33).John Wiley \& Sons.

vi. Akman, I., \& Mishra, A. (2009). Ethical behavior issues in software use: An analysis of public and private sectors. Computers in Human Behavior, 25(6), 1251-1257.

vii. Bavakutty, M., \& T. K. Salih Muhamad, (1999). Internet Services in Calicut University. Conference, Academic Libraries in the Internet Era. Proceedings of the $6^{\text {th }}$ National Convention on Academic Libraries in the Internet Era. pp37-44.

viii. Bimber, B. (2000). "Measuring the gender gap on the internet." Social Science Quarterly 81, 868-76.

ix. Binder, M., \& Niederle, U. (2007). Institutions as determinants of preference change- A one way relation? Retrieved May 16, 2016, from https:/ / papers.econ.mpg.de/ evo/ discussion papers/ 2006-07.pdf

x. Brosnan, M., \& Lee, W. (1998). A cross-cultural comparison of gender differences in computer attitudes and anxieties: The United Kingdom and Hong Kong, Computers in Human Behavior, 14 (4), 559-577.

xi. Cohen, J. (1988). Statistical power analysis for the behavioral sciences (2nd ed.). Hillsdale, NJ: Lawrence Earlbaum Associates.

xii. Curriculum Research and Development Division (2007a). Teaching Syllabus for Information and Communications Technology (Core): Senior High School. Accra, Ghana: Ministry of Education Science and Sports.

xiii. Davis, F. D. (1989). Perceived usefulness, perceived ease of use, and user acceptance of information technologies, MIS Quarterly, 13(3), 319-340.

xiv. Davis, F. D. (1993). "User acceptance of information technology: system characteristics, user perceptions and behavioral impacts", International Journal of Man-Machine Studies, 38, 475-87

xv. Davis, F. D., Bagozzi, R. P. \& Warshaw, P. R. (1989). “User acceptance of computer technology: a comparison of two theoretical models". Management Science, 35, 8, 982-1003

xvi. Dishaw, M. T. \& Strong, D. M. (1999), 'Extending the Technology Acceptance Model with task-technology fit constructs', Information \& Management, 36, 1, 9-21.

xvii. Doggan, A., Hess, B., Mogan, D., Kim, S., \& Wilson, K. (1999). Measuring students' attitude towards educational use of the internet. Paper presented at - the Annual Conference of the American Educational Research Association.

xviii. Durndell, A., Haag, Z.., \& Laithwaite, H. (2000). Computer self-efficacy and gender: across cultural study of Scotland and Romania, Personality and Individual Differences, 6(1), 1037-1044.

xix. Gahtani SA (2001). The applicability of TAM outside North America: an empirical test in the United Kingdom. Information Resource Management Journal. 2, 37-46.

xx. Garland, K. J., \& Noyes, J. M. (2005). Attitudes and confidence towards computers and books as learning tools: A crosssectional study of student cohorts. British Journal of Educational Technology, 36, 85-91.

xxi. Gefen, D, \& Straub, D. (2000). The relative importance of perceived ease of use in IS adoption: a study of e-commerce adoption. Journal Association Information Systems. 1(8): 1-28.

xxii. Hills, P. and Argyle, M. (2003). Uses of the Internet and their relationships with individual differences in personality. Computers in Human Behavior 19, (1), 59-70.

xxiii. Hong, K. S., Ridzuan, A. A., \& Kuek, M. K. (2003). Students' attitudes towards the use of the Internet for learning: A study at a university in Malaysia. Educational Technology and Society, 6(2), 45-49.

xxiv. Hong, W., Thong, J. Y. L., Wong, W. M., \& Tam, K. Y. (2002). Determination of user acceptance of digital libraries: An empirical examination of individual difference and system characteristics, Journal of Management Information System. 18(3), 97-124.

xxv. Joyce, M., \& Kirakowski, J. (2013). Development of a general internet attitude scale. In Marcus, A. ed. Design, User Experience, and Usability. Design Philosophy, Methods, and Tools, 250-260, Third International Conference. DUXU 2014, Held as Part of HCI International 2014, Heraklion, Crete.

xxvi. Khaled, N. A. O. (2012). Attitudes towards the use of the internet: A study at Teachers College at King Saud University. Psychology Research. 2, (3), 151-159.

xxvii. Mathieson, K. (1991). Predicting user intentions: Comparing the technology acceptance model with the theory of planned behavior. Information Systems, Resources. 2, 173-191.

xxviii. Mathwick, C., Malhotra, N. and Rigdon, E. (2001) 'Experiential value: Conceptualization, measurement and application in the catalog and internet shopping environment'.Journal of Retailing 77,(1): 39-56. 
xxix. Metzger, M. J., Flanagin, A. J., \& Zwarun, L. (2003). College student web use, perceptions of information credibility and verification behavior. Computers and Education, 41, 271-290.

xxx. Mitra, A. \& Steffensmeier, T. (2000). Changes in students' attitudes and student computer use in a computer enriched environment. Journal of Research on Technology in Education, 32 (3), 417-433.

xxxi. Morris, D., \& Trushell, J. (2014). Computer programming, ICT and gender in the

a. classroom: a male-dominated domain or a female preserve? Research in teacher education,1, 4-9.

xxxii. Nabeel, S. Shahrir, J. \& Leng, C. H. (2013). Measuring attitude towards computer and internet usage among postgraduate students' in Malaysia. The Turkish Online Journal of Educational Technology. 12(2).

xxxiii. Nysveen, H., Pedersen, P. E., \& Thornbjomsen, H. (2005). Intentions to use mobile services: Antecedents and crossservice comparisons. Journal of Academy of Marketing Science, 33(3). 330-346.

xxxiv. Sam, H. K., Othman, A. E. A., \& Nordin, Z. S. (2005). Computer Self-Efficacy,Computer Anxiety, and Attitudes toward the Internet: A Study among Undergraduates in Unimas, Educational Technology \& Society, 8 (4), 205-219.

xxxv. Sanni, M. ,Awoleye O. M., Egbetokun A. A., \&Siyanbola W. O (2009). Harnessing the potentials of internet technology for research and development among undergraduates in Nigeria: A case study of Obafemi Awolowo University. International Journal of Computing and ICT Research, 3,( 1).

xxxvi. Sekaran, U. (2003). Research methods for business ( $4^{\text {th }}$ ed.). Hoboken, NJ: John Wiley \& Sons.

xxxvii. Slate, J.R., Manuel, M., \& Brinson, JR.K. (2002). The “digital divide”: Hispanic college students' views of educational uses of the internet. Assessment \& Evaluation in Higher Education, 27(1), 75-93.

xxxviii. Smith, B., Caputi, P., \& Rawstone, L. (2000). Differentiating computer experience and attitude towards computers: An empirical investigation. Computers in Human Behavior, 16, 59-81.

xxxix. Stewart, B. (Ed), (2000). The Living Internet, "Information Processing Techniques Office".

xl. Taylor, S., \& Todd, P. (1995). Decomposition and crossover effects in the theory of planned behavior: A study of consumer adoption intentions. International Journal of Research in Marketing, 12-(2), 137-155.

xli. Thong, J. Y. L., Hong, W., \& Tam, K. Y. (2004). What leads to user acceptance of digital libraries? Communications of the $\mathrm{ACM}, 47(11), 79-83$.

xlii. Tuncer, M. (2013). An analysis on the effect of computer self-efficacy over scientific research self- efficacy and information literacy self-efficacy. Educational Research and Reviews Journal. 8(1), 1-33

xliii. Usun, S. (2003). Undergraduate students attitudes towards educational uses of internet, Interactive Educational Multimedia, 7, 46-62.

xliv. Venketesh, V. \& Davis, F. D. (2000). "A theoretical extension of the technology acceptance model: four longitudinal field studies”, Management Science, 46 (2), 186-20 